\title{
Molecular identification and phytochemical profiling of kamiling (wild toxic plant) using thin layer chromatography
}

\author{
Dana Theresa C. De Leon ${ }^{1}$, John Dave C. Aquino ${ }^{2}$, \\ Mary Jhane G. Valentino ${ }^{(1)}$, Jerwin R. Undan ${ }^{(*), 3,4,5}$
}

\footnotetext{
${ }^{1}$ Tuklas Lunas Center, Central Luzon State University, Science City of Munoz, Nueva Ecija Philippines.

${ }^{2}$ Research Extension and Training, Central Luzon State University, Science City of Muñoz, Nueva Ecija 3120 Philippines.

${ }^{3}$ Faculty, Department of Biology, College of Arts and Sciences, Central Luzon State University, Science City of Muñoz, Nueva Ecija 3120 Philippines.

${ }^{4}$ Molecular Biology and Biotechnology Laboratory, Department of Biological Sciences, College of Arts and Sciences, Central Luzon State University, Science City of Munoz, Nueva Ecija Philippines

${ }^{5}$ Biotechnology and Analytical Laboratory, Central Luzon State University, Science City of Muñoz, Nueva Ecija 3120 Philippines.
}

\begin{abstract}
Some plants may only be known by the people in their own respective place. Consequently, there is a need for the authentication and further study of wild toxic plant known by indigenous people. The genomic DNA from the leaves of the plant Kamiling collected in Imugan, Santa Fe, Nueva Vizcaya, Philippines was extracted and amplified using $m a t \mathrm{~K}$ and $r b c \mathrm{~L}$ gene markers. Sample sequences was queried on GenBank using Basic Local Alignment Search Tool (BLAST) revealed that the sample sequences were identified as Semecarpus cuneiformis using both on $m a t K$ and $r b c \mathrm{~L}$ markers. The leaves of Kamiling was subjected through Thin Layer Chromatography (TLC) and it revealed important phytochemicals such as alkaloids, coumarins, anthraquinones, anthrones, tannins, flavonoids, higher alcohols, phenols, steroids and essential oils. Since there is a growing awareness in correlating the phytochemical constituents of plants with their pharmacological activity, wild toxic plant can be one of the preferences for medicinal uses.
\end{abstract}

\section{ARTICLE HISTORY}

Received: 30 March 2018

Revised: 16 July 2018

Accepted: 20 July 2018

\section{KEYWORDS}

TLC,

mat $\mathrm{K}$

$r b c \mathrm{~L}$,

wild toxic plant

\section{INTRODUCTION}

Exploring new medicine have been common to people and plays a big role with the application of plants in this field. A large number of plants with different roles on curing specific disease have been identified. Every plant has its own component that could have been use for treating disease. And so as people continue exploring to develop and determine the uses of plants which can be found in area that is conserved.

CONTACT: Jerwin R. Undan $\square$ jerwinundan@clsu.edu.ph @ Faculty, Department of Biology, College of Arts and Sciences, Central Luzon State University, Science City of Muñoz, Nueva Ecija 3120 Philippines 
Kamiling is wild tree that is mostly found in habitat of dry grassland, open slopes, moist and dry thickets this is a small tree growing to a height of 12 meters. Leaves are crowded at the end of the branches, lanceolate-obovate to oblong-obovate, 10 to 25 centimeters long, hairy, whitish beneath, rounded or somewhat pointed at the tip and usually pointed at the base. In the Philippines the leaves of the tree are regarded as poisonous, it can cause severe itchiness and swelling of eyes and face when touch. The tree is native usually in range of Taiwan, Indonesia, and Philippines [1]. Although many persons are probably immune to poisoning from the hairs on the leaves, in the Philippines the plant is usually regarded as poisonous, with reports of severe contact dermatitis. The sap is considered a violent contact poison which can cause painful swelling and minute blistering pustular skin eruptions. [2].

Plants have the ability to synthesize a wide variety of chemical compounds that are used to perform important biological functions and to defend against attack from predators such as insects, fungi, and herbivorous mammals. Many of these phytochemicals have beneficial effects on long-term health when consumed by humans, and can be used to effectively treat human diseases [3].

With the progress of phytochemical research more and more plant constituents have been isolated and identified. For the alkaloids alone, there are over 5,500 compounds and the growing interest in its pharmacological activities have led to further investigations. It is estimated that new compound is being discovered and described at a rate of one per day [4]. Thin-layer chromatography coupled with biological detection can be considered as a high-throughput, inexpensive and reliable procedure for screening plant extracts for the presence of potential drugs [5].

Because of the increasing demand for remedies and for authentication of the source material, it is vital to provide a single database containing information about authentic plant materials and their potential adulterants. The database should provide DNA barcodes for data retrieval and similarity search. In order to obtain such barcodes, several molecular methods have been applied to develop markers that aid with the authentication and identification of medicinal plant materials. The study of plant molecular determination will discuss the genomic regions and molecular methods selected to provide barcodes, available databases and the potential future of barcoding using next generation sequencing [6].

\section{MATERIALS AND METHODS}

\subsection{Collection and Preservation of the Sample}

Plant material was collected at Imugan Falls, Sta. Fe Nueva Vizcaya, Philippines. Imugan falls is a thirty-five-foot tall crystal clear waters resting up in the Caraballo Range falling into a shallow basin-like pool which flows all the way to Imugan River. The elevation above sea level is about 1685 meters.

Fresh young leaves of Kamiling was collected by using a knife and hand-picked with gloves. The sample was cleaned using fine brush and external moisture was wiped out with a dry cloth. It was placed in a container and then air dried condition for 5 days and kept for the preparation of the analysis of the phytochemicals. For the molecular identification, fresh leaves were put in a secured plastic bag and refrigerated in $-80^{\circ} \mathrm{C}$ freezer until the preparation for DNA extraction.

\subsection{DNA Extraction, PCR amplification and Sequencing}

DNA from the leaves of Kamiling was extracted using CTAB method by Murray and Thompson (1980) [7] with few modifications. The DNA was then checked by loading a $2 \mu 1$ DNA in 1\% agarose gel and run through electrophoresis (Enduro Gel XL). The DNA was run through PCR machine (2720 Thermal Cycler) using matK primer pair (F:5'- 
CCCRTYCATCTGGAAATCTTGGTTC-3' and R: 5'-GCTRTRATAATGAGAAAGATTTCTGC-3') and $r b c \mathrm{~L}$ primer pair (F: 5'-ATGTCACCACAAACAGAGACTAAAGC-3' and R: 5'TCGCATGTACCTGCAGTAGC-3'). One (1) $\mu 1$ of diluted DNA was mixed with PCR components and the PCR profile was set as follows: 35 cycles with an initial denaturation at $94^{\circ} \mathrm{C}$ for 5 minutes, final denaturation at $94^{\circ} \mathrm{C}$ also for 30 seconds, annealing at $56^{\circ} \mathrm{C}$ for 30 seconds, extension at $72^{\circ} \mathrm{C}$ for 45 seconds, final extension for 10 minutes at $72^{\circ} \mathrm{C}$ and hold at $10^{\circ} \mathrm{C}$. Final mixtures of PCR components and DNA were transferred to PCR tubes and were subjected to PCR reaction to amplify the mat K and $r b c \mathrm{~L}$ region of each specimen. PCR components were made up of $2.5 \mu \mathrm{l}$ of $10 \mathrm{x}$ PCR Buffer, $1.5 \mu \mathrm{l}$ of $25 \mathrm{Mgcl} 2,1.25 \mu \mathrm{l}$ of 10 DNTP mix, $1.13 \mu \mathrm{l}$ of ITS 3D and ITS $4,0.09 \mu 1$ of Taq polymerase and $15.4 \mu 1$ of dH20 which has a total volume of $25 \mu \mathrm{l}$ together with $2 \mu \mathrm{l}$ of DNA. Again the PCR products were loaded to agarose gel to check the quality of DNA and electrophoresis was carried out at $100 \mathrm{~V}$ for $30 \mathrm{~min}$. Samples with amplification were stored in the tubes, sealed with parafilm and was sent to $1^{\text {st }}$ BASE Laboratory in Malaysia for PCR purification and sequencing procedure. The sequences were queried on BLAST (basic local alignment search tool) to check the percent similarity in Genbank.

\subsection{Phytochemical Profiling}

The secondary metabolites present in the plant leaf extracts were determined using thin layer chromatography based on Aguinaldo et al. (2005) [4] TLC is less time consuming, low cost, and can be performed with less complicated technique it has a wide application in pharmaceutical analysis [8]. Also it has a wide application in identifying impurities in a compound. It can be used as a preliminary analytical method prior to HPLC. The dried sample was homogenized using blender. About 2 to $3 \mathrm{~g}$ of dried powdered plant material was defatted with $10 \mathrm{~mL}$ of hexane or petroleum ether and was heated over a water bath for 5 minutes. After which the solvent was then decanted and discarded. The defatted plant residue was treated with $10 \mathrm{~mL}$ of a mixture of chloroform and acetic acid, $\mathrm{CHCl}_{3}: \mathrm{CH}_{3} \mathrm{COOH}(99: 1 \mathrm{v} / \mathrm{v})$ and heat for 5 to 10 minutes over a water bath; the solution was then filtered and labelled the filtrate as Solution A. Resulting residue was treated with $10 \mathrm{~mL}$ of a mixture of chloroform, methanol and acetic acid, $\mathrm{CHCl}_{3}: \mathrm{CH}_{3} \mathrm{OH}: \mathrm{CH}_{3} \mathrm{COOH}(49.5: 49.5: 1)$ and heat for 5 to 10 minutes over a water bath; it was then filtered and the filtrate was labelled as Solution B. The residue was extracted with $10 \mathrm{~mL}$ of a mixture of methanol and water, $\mathrm{CH} 3 \mathrm{OH}: \mathrm{H} 2 \mathrm{O}(1: 1)$ and heat over a water bath for 5 to 10 minutes. The solution was then filtered and the filtrate was labeled the as Solution C. The plant residue was then discarded. All reagents and solvents used were analytical grade.

Thin layer plates (Merck Millipore) was cut into size of 1 inch by 2 inch. The plates were mark $0.5 \mathrm{~mm}$ in both sides. To screen the plant extract using TLC, the chromatogram was developed with different solvent systems as suggested in Table 1 [4]. It was air dried and visualized with the following spray reagents as shown in Table 2 [4].

Table 1. Groups of plant constituents that would possibly be distributed in the different extracts

\begin{tabular}{ll}
\hline Extracting Solvents & Plant Constituents \\
\hline Mixture of chloroform and acetic acid & $\begin{array}{l}\text { Solution A } \\
\text { Anthraquinones, phenols, flavonoids, steroids, } \\
\text { coumarins }\end{array}$ \\
\hline $\begin{array}{l}\text { Mixture of chloroform, methanol and } \\
\text { acetic acid }\end{array}$ & $\begin{array}{l}\text { Solution B } \\
\text { Flavonoid glycosides, cardenolides, anthraquinone } \\
\text { glycosides, tannins, saponins, coumarins, indoles }\end{array}$ \\
\hline Mixture of methanol and water & $\begin{array}{l}\text { Solution C } \\
\text { Flavonoid glycosides, anthraquinone glycosides, } \\
\text { cardenolides, saponins, indoles, sugar, higher alcohols }\end{array}$ \\
\hline
\end{tabular}


Table 2. List of plant constituents, their visualizing agents and indication of a positive test

\begin{tabular}{|c|c|c|}
\hline Constituents Tested & Spray Reagent & Observable results for positive test \\
\hline $\begin{array}{l}\text { Flavonoids } \\
\text { Steroids }\end{array}$ & Antimony (III) chloride & $\begin{array}{l}\text { Intense yellow to orange visible zone appear } \\
\text { on spraying for glycosidic flavonoids } \\
\text { fluorescent colors under UV } 365 \mathrm{~nm}\end{array}$ \\
\hline $\begin{array}{l}\text { Phenols } \\
\text { Tannins } \\
\text { Flavonoids }\end{array}$ & $\begin{array}{l}\text { Potassium ferricyanide- } \\
\text { ferric chloride }\end{array}$ & Blue spots \\
\hline Alkaloids & Dragendorff's reagent & $\begin{array}{l}\text { Brown- orange visible spots immediately on } \\
\text { spraying colors aren stable }\end{array}$ \\
\hline Cardenolides & $\begin{array}{l}\text { 3,5 Dinitrobenzoic acid; } \\
\text { Kedde reagent }\end{array}$ & Blue to red- violet colored zones \\
\hline $\begin{array}{l}\text { Coumarins } \\
\text { Anthraquinones, } \\
\text { anthrones } \\
\text { Phenols }\end{array}$ & $\begin{array}{l}\text { Methanolic potassium } \\
\text { hydroxide (Borntrager } \\
\text { reagent) }\end{array}$ & $\begin{array}{l}\text { Anthraquinones give orange coloration } \\
\text { Anthrones give yellow (UV365 nm) zones } \\
\text { Coumarins react to form blue (UV365 nm) } \\
\text { colored zone }\end{array}$ \\
\hline Anthraquinones & Magnesium acetate & Orange- violet color \\
\hline Indoles & Van Urk- Salkowski Test & Blue- violet spots \\
\hline $\begin{array}{l}\text { Higher alcohols } \\
\text { Phenols } \\
\text { Steroids } \\
\text { Essential oils }\end{array}$ & Vanillin- sulfuric acid & $\begin{array}{l}\text { Triterpenes and sterols appear mainly as } \\
\text { blue- violet spots. Essential oil form zones } \\
\text { with a wide range of colors. }\end{array}$ \\
\hline Sugars & Naphthol- sulfuric acid & Blue spots \\
\hline
\end{tabular}

\section{RESULTS}

\subsection{Molecular Identification}

The Kamiling was amplified with the gene specific primer matK and $r b c \mathrm{~L}$ after the first two trials of amplification. To confirm the identity of the plant species, the DNA sequences of the amplified products were used for BLAST analysis. After the BLAST analysis, results both on $m a t \mathrm{~K}$ and $r b c \mathrm{~L}$ primers showed that it was Semecarpus australianensis. However, the related nucleotide sequences identified using BLAST do not conform to the morphological characteristics and the distribution of Kamiling. The Kamiling was identified under the family Anacardiaceae, genus Semecarpus and named the species as Semecarpus cuneiformis identified by Blanco [10].

\subsection{Phytochemical Profiling using TLC}

Different extracting solvent was used to know the polarity of the plant constituents Table 1 . Among the different extracts and various solvent system used, only in chloroform-methanol extract and in the solvent system of Toluene-acetone chloroform it develops. Upon spraying, Dragendorff's reagent, reveals that alkaloid is present in the plant leaf. Moreover, Borntrager reagent shows the occurrence of coumarins, anthraquinones, anthrones and phenols. Furthermore, vanillin-sulfuric acid, revealed the presence of higher alcohols, phenols, steroids and essential oils (Table 3). 
Table 3. Phytochemical profiling of various fractions of Semecarpus cuneiformis

\begin{tabular}{|c|c|c|c|c|}
\hline Test Solutions & $\begin{array}{l}\text { Constituents } \\
\text { Tested }\end{array}$ & $\begin{array}{l}\text { Extracting Solvent } \\
\text { Chloroform+Acetic Acid } \\
\text { Solvent system (Toluene- } \\
\text { acetone- chloroform) }\end{array}$ & Observable Results & RF value \\
\hline $\begin{array}{l}\text { Antimony III } \\
\text { chloride }\end{array}$ & $\begin{array}{l}\text { Flavonoids } \\
\text { Steroids }\end{array}$ & - & & $\begin{array}{l}1.342 \mathrm{~cm} \\
1.208 \mathrm{~cm}\end{array}$ \\
\hline $\begin{array}{l}\text { Potassium } \\
\text { ferricyanide- } \\
\text { ferric chloride }\end{array}$ & $\begin{array}{l}\text { Phenols } \\
\text { Tannins } \\
\text { Flavonoids }\end{array}$ & - & & $\begin{array}{l}1.549 \mathrm{~cm} \\
1.341 \mathrm{~cm} \\
1.146 \mathrm{~cm}\end{array}$ \\
\hline $\begin{array}{l}\text { Dragendorff's } \\
\text { reagent }\end{array}$ & Alkaloids & + & $\begin{array}{l}\text { Brown- orange visible } \\
\text { spots }\end{array}$ & $1.169 \mathrm{~cm}$ \\
\hline Cardenolides & Cardenolides & - & & $1.157 \mathrm{~cm}$ \\
\hline $\begin{array}{l}\text { Methanolic } \\
\text { potassium } \\
\text { hydroxide } \\
\text { (Borntrager } \\
\text { reagent) }\end{array}$ & $\begin{array}{l}\text { Coumarins } \\
\text { Anthraquinon } \\
\text { es } \\
\text { Anthrones } \\
\text { Phenols }\end{array}$ & + & $\begin{array}{l}\text { Anthraquinones give } \\
\text { orange coloration } \\
\text { Anthrones give yellow } \\
\text { (UV365 nm) zones }\end{array}$ & $\begin{array}{l}1.864 \mathrm{~cm} \\
1.781 \mathrm{~cm} \\
1.492 \mathrm{~cm} \\
1.218 \mathrm{~cm}\end{array}$ \\
\hline $\begin{array}{l}\text { Vanillin- } \\
\text { sulfuric acid }\end{array}$ & $\begin{array}{l}\text { Higher } \\
\text { alcohols } \\
\text { Phenols } \\
\text { Steroids } \\
\text { Essential oils }\end{array}$ & + & Blue- violet spots & $\begin{array}{l}1.960 \mathrm{~cm} \\
1.810 \mathrm{~cm} \\
1.388 \mathrm{~cm} \\
1.220 \mathrm{~cm}\end{array}$ \\
\hline $\begin{array}{l}\text { Magnesium } \\
\text { acetate }\end{array}$ & $\begin{array}{l}\text { Anthraquinon } \\
\text { es }\end{array}$ & - & & $1.938 \mathrm{~cm}$ \\
\hline Indoles & Indoles & - & & $2.036 \mathrm{~cm}$ \\
\hline
\end{tabular}

\section{DISCUSSION}

\subsection{Molecular Identification}

Conferring to all the present gathered data, the one showed $99 \%$ identity of the sample was identified as Semecarpus australianensis, but based on the previous literatures the Semecarpus australianensis can be found only in the Northern Terittory, Cape York Peninsula, and Wet Tropics of Queensland Australia, Torres Strait Islands, New Guinea, New Britain, Aru Islands and additional Pacific Islands (9), the said plant sample has no record in the Philippines species base on the identification of it under family Anacardiaceae [10, 11]. Kamiling was described and classified as Semecarpus cuneiformis based on the morphology and availability of the species in the vast areas of the country.

\subsection{Phytochemical Profiling using TLC}

Since wild toxic plant is often disregarded, by profiling Semecarpus cuneiformis it was found out that it may possibly cure and prevent various diseases based on the positive results recorded. The diverse pharmacological activities of anthrones, anthraquinones includes immunological adjuvant and wound healing, antimicrobial, antioxidant, laxative activities and modulation of apoptosis [12].

While coumarins are used as antifungal and anticoagulant reagents [13]. Plant material that contains phenolic compounds also has as antimicrobial and anti-inflammatory activity [14]. Whereas alkaloids have many pharmacological uses including, antihypertensive effects, antiarrhythmic effects, antimalarial activity and anti-cancer actions. Furthermore, plant contains steroids that can be useful to decrease the amount of cholesterol in a body. And also, many 
essential oils have antibacterial, antimicrobial, antiviral, anti-inflammatory, antiseptic, and antibiotic properties.

Since the plant material has a good source of secondary metabolites, this can be used in many aspects in pharmacology. As mentioned, alkaloids, anthraquinones and anthrones has apoptotic activity, S. cuneiformis might be one of the solution to discovery of another medication for cancer. Considering that there is a lot of antimicrobial, anti-inflammatory, antioxidant and anticoagulant product commercially, it still good to discover alternative source of material such as this plant which is neglected due to its toxicity effect. This research work that focused on phytochemical analysis shows the presence of the phytochemical constituents of S. cuneiformis. The phytochemical profiling was significant especially in the case of unharmed plants for the knowledge of their pharmacological activity.

\section{ORCID}

Mary Jhane G. Valentino (D) https://orcid.org/0000-0003-3814-5478

Jerwin R. Undan (D) https://orcid.org/0000-0002-3657-1732

\section{REFERENCES}

[1] Godofredo, S. (2015). Semecarpus cuneiformis Blanco. Philippine Medicinal Plant. Retrieved from http://www.stuartxchange.com/Ligas.html.

[2] Bhatia, K., Kataria R., Singh A., Zainab HS. \& Kumar R. (2014) Allergic Contact Dermatitis by Semecarpus anacardium for Evil Eye: A prospective study from Central India. Indian Journal of Basic and Applied Medical Research, 3(3) P-122-127.

[3] Cobiac, L. (2006). Herbal Medicines: A guide for health-care professionals. Pharmaceutical Press, 28(1), 303-335.

[4] Aguinaldo A.M., Espeso E.I., Guevara B.Q., and Nonato M. G. (2005). A Guidebook to Plant Screening: Phytochemical and Biological/ Beatrice Q. Guevara, ed. -Revised ed.Manila: Research Center for the Natural Sciences, University of Sto Tomas.

[5] Waksmundzka-Hajnos, M \& M.A., Hawryl \& Ciesla, Lukasz. (2014). Analysis of Plant Material. Instrumental Thin-Layer Chromatography, 505-554. doi.org/10.10166/B978-012-417223-4.00019-4.

[6] Techen, N., Parveen, I., Pan, Z., Khan, I. (2014). DNA barcoding of medicinal plant material for identification. Current Opinion in Biotechnology, 25, 103-110.

[7] Murray, M. G., and Thompson, W. F. (1980). Rapid isolation of high molecular weight plant DNA. Nucleic Acids Research, 8(19), 4321-4326.I

[8] Bele, A.A., \& Khale, A. (2011) An overview on thin layer chromatography, IJPSR, 2(2), 2011, 256-267.

[9] Low, T., (1991) Wild Foods of Australia, ISBN 0-207-16930-6

[10] Pelser, P. (2012). Co's Digital Flora of the Philippines; Anacardiaceae. Semecarpus cuneiformis Blanco Fl, Filip. Retrieved from www.philippineplants.org/Families/Anacardiaceae.html

[11] Pell, K. S. (2004). Molecular systematics of the cashew family (Anacardiaceae). Plant Biology. Electronic Thesis and Dissertation. Retrieved from http://etd.lsu.edu/docs/available/etd-04152004-101232/unrestricted/Pell_dis.pdf

[12] Mazimba, O., Wale, K., Kwape, T. E. Mihigo, S.O., Bokolo, M.K. (2015). Cinnamomum verum: ethylacetate and methanol extracts antioxidant and antimicrobial activity. Journal of Medicinal Plants Studies, 3(3), 28-32. 
[13] Talapatra, S.K., Talapatra, B. (2015). Chemistry of plant natural products: Stereochemistry, Conformation, Synthesis, Biology, and Medicine. Springer, Heidelberg, New York.

[14] Hoffman, D. (2003). Medical Herbalism, the Science and Practice of Herbal Medicine. Healing Arts Press, 1, 303-360. 